\title{
An Empirical Based Proposal for Mass Customization Business Model in Footwear Industry
}

\author{
Golboo Pourabdollahian, Donatella Corti, Chiara Galbusera, \\ and Julio Cesar Kostycz Silva \\ Politecnico di Milano, Piazza Leonardo Da Vinci 32, 20133, Milan, Italy \\ golboo.pourabdollahian@mail.polimi.it, donatella.corti@polimi.it
}

\begin{abstract}
This research aims at developing a business model for companies in the footwear industry interested in implementing Mass Customization with the goal of offering to the market products which perfectly match customers' needs. The studies on mass customization are actually mostly focused on product development and production system aspects. This study extends the business modeling including also Supply Chain aspects. The research is based on analyzing Mass Customization application in reality, within some companies operating in footwear industry. Through the real cases of Mass Customization implementation, a business model proposal is developed as an attempt to generalize the empirical findings.
\end{abstract}

Keywords: Mass Customization, Business Model, Footwear industry.

\section{Introduction}

Nowadays globalization has radically changed the industrial environment not only by creating a higher market turbulence and competition but also by increasing number of demanding customers which ask for unique products that perfectly match their needs and preferences. In this regard the adoption of a mass customization (MC) approach has been considered as a proper solution since it provides customers with individualized goods while being efficient at the same time. Considering the increasing interest of a higher number of companies to offer mass customized products, it is crucial to provide companies with a proper business model enabling them to implement $\mathrm{MC}$ in a successful manner. Going through literature, we found out that there is no proposal for a MC business model; hence this research aims at developing an empirical based MC business model for footwear industry to support companies since this sector in successful implementation of this strategy. The research is limited to footwear industry due to the fact that business model is highly sector dependent; therefore it is not easy to define a general business model which can be applied in all sectors. Moreover considering the fact that this research is an empirical based study, footwear industry was selected since it is a popular sector for implementation of mass customization with considerable amount of existing and emerging actors in the sector. 


\section{Business Model: Definition and Reference Structure}

From the very early emergence of the term "Business model" by Jones [4] different definitions have been suggested in literature to define the term and its role. These definitions reflect different perspectives which can be targeted by a business model such as value creation, simplification of a complex system, money generation, company behavior representation and etc. In this study we refer to Osterwalder to define business model as "a conceptual tool that contains a set of elements and their relationships and allows expressing a company's logic of earning money."[6] The reference structure for the analysis of a business model in this study is the one proposed by Osterwlader and Pigneur's (called business model canvas) with minor modifications needed to adopt it to the context of interest [7]. The initial business model canvas of Osterwlader and Pigneur includes 9 building blocks that can be logically grouped into 3 areas: Left side relates to efficiency (Key partners, key activities, key resources, and cost structure), the right side relates to value delivery (Customer segment, customer relationship, channels, and revenue streams) and finally the value proposition which is in between. The proposed change is the merging of the costs and revenues blocks into a single one named performance. This is mainly due to the fact that in a mass customization business not only cost and revenue are considered as critical issues but also evaluation of customization and efficiency level of the firm is important. Therefore the final structure of the business model is based on eight blocks illustrated in figure 1.

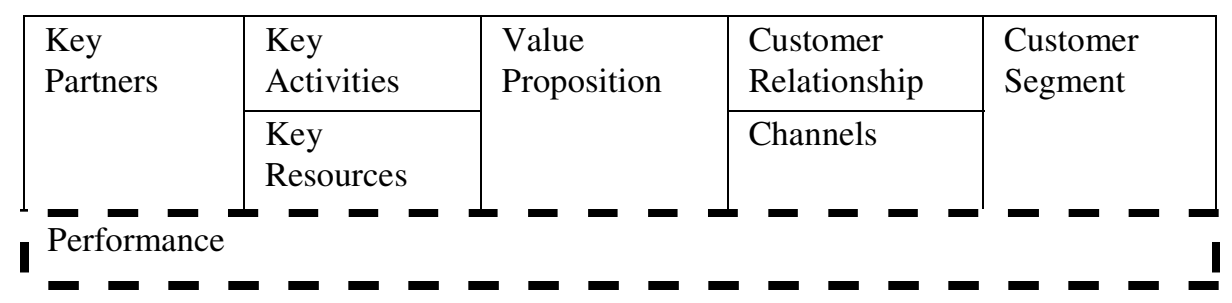

Fig. 1. Business model structure

\section{$3 \quad$ Research Methodology}

In order to come out with the empirical based MC business model for the footwear industry, we selected five companies in different countries operating in footwear industry that propose customized shoes to their customers. The analysis comprehends both cases of small companies and cases of medium/large companies, also already established companies with standard products and start-up mass customized born companies. Data were collected through different primary and secondary sources including: questionnaire, personal interview, papers, releases and publications on scientific magazines, official company website, official financial reports, blogs, forums, communities and online sector magazine release. Table 1 presents a summary of information to introduce the five analyzed cases. For each case study the analysis of the business model in place has been carried out based on the use of the abovementioned canvas. 
Table 1. Analyzed case studies

\begin{tabular}{|l|l|l|l|l|l|}
\hline Company & Country & $\begin{array}{l}\text { Foundation } \\
\text { year }\end{array}$ & Size & $\begin{array}{l}\text { Mass } \\
\text { production } \\
\text { beside MC }\end{array}$ & Type of shoes \\
\hline A & Germany & 1924 & Large & Yes & Sport \\
\hline B & USA & 1978 & Large & Yes & Sport \\
\hline C & Brazil & 2011 & SME & No & Sneakers \\
\hline D & Germany & 2001 & SME & No & luxury shoes \\
\hline E & Australia & 2009 & SME & No & $\begin{array}{l}\text { Women's } \\
\text { shoes }\end{array}$ \\
\hline
\end{tabular}

\section{Cross Analysis}

Based on the cases analysis a set of different alternatives for each block of business model were identified and mapped (Table 2). These alternatives are mainly based on best practices of the analyzed companies. Obviously some of them have been applied by only one company while some others are applied by more companies. This is due to the fact that the analyzed cases vary in some factors such as size, customer segment and the level of customization they offer to their customers. In order to better demonstrate the position of each alternative in a MC solution space we defined three pillars for solution space naming product (PR), production system (PS) and supply chain (SC) and we allocated each alternative to the most suitable solution space pillar. This might facilitate for a company the act of focusing on a preferred pillar of solution space without compromising other important aspects of solution space.

Table 2. MC alternatives applied in case studies

\begin{tabular}{|c|c|c|c|c|c|c|}
\hline BM Block & SS Pillar & Company A & Company B & Company C & Company D & Company E \\
\hline 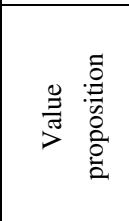 & PR & $\begin{array}{c}\text { Customization } \\
\text { (Style, function, } \\
\text { fit) }\end{array}$ & $\begin{array}{c}\text { Customization } \\
\text { (Style, } \\
\text { function) }\end{array}$ & \begin{tabular}{|} 
Customization \\
(Style, \\
packaging), \\
Customer \\
involvement in \\
parts design
\end{tabular} & $\begin{array}{c}\text { Customization } \\
\text { (Style, fit), } \\
\text { Customers' } \\
\text { feedback on raw } \\
\text { material quality }\end{array}$ & \begin{tabular}{|c} 
Customization \\
(Style), \\
Customized \\
reusable \\
packaging
\end{tabular} \\
\hline \multirow{3}{*}{ 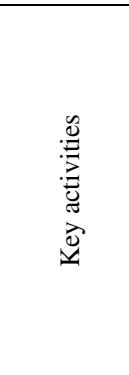 } & PR & \multicolumn{5}{|c|}{$\begin{array}{l}\text { Product modularization \& components standardization, solution space definition, } \\
\text { customers' requirements elicitation }\end{array}$} \\
\hline & PS & & & $\begin{array}{l}\text { Implement } \\
\text { postponement }\end{array}$ & & \\
\hline & SC & $\begin{array}{l}\text { Integrate with } \\
\text { logistics partners, } \\
\text { Employees } \\
\text { training, } \\
\text { Information } \\
\text { management }\end{array}$ & \begin{tabular}{|l|} 
Integrate with \\
logistics \\
partners, \\
Employees \\
training
\end{tabular} & & $\begin{array}{l}\text { Integrate with } \\
\text { logistics } \\
\text { partners, } \\
\text { Employees } \\
\text { training }\end{array}$ & $\begin{array}{l}\text { Integrate with } \\
\text { logistics } \\
\text { partners, } \\
\text { Employees } \\
\text { training }\end{array}$ \\
\hline 0 is 0 & PR & & Designers & & & Designers \\
\hline
\end{tabular}


Table 3. (Continued.)

\begin{tabular}{|c|c|c|c|c|c|c|}
\hline & PS & & & $\begin{array}{l}\text { Flexible } \\
\text { manufacturing } \\
\text { system }\end{array}$ & & \\
\hline & $\mathrm{SC}$ & $\begin{array}{l}\text { Online } \\
\text { configurator, } \\
\text { trained } \\
\text { personnel, IT } \\
\text { infrastructure }\end{array}$ & $\begin{array}{c}\text { Online } \\
\text { configurator }\end{array}$ & $\begin{array}{c}\text { Online } \\
\text { configurator }\end{array}$ & $\begin{array}{c}\text { Online } \\
\text { configurator, } \\
\text { Trained } \\
\text { personnel, } \\
\text { Point of sale } \\
\text { systems }\end{array}$ & $\begin{array}{l}\text { Online } \\
\text { configurator, } \\
\text { Experts to } \\
\text { support } \\
\text { customer in } \\
\text { co-design }\end{array}$ \\
\hline 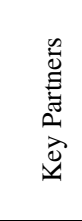 & $\mathrm{SC}$ & $\begin{array}{l}\text { Shoe producer, } \\
\text { Logistic partner, } \\
\text { customers }\end{array}$ & $\left\{\begin{array}{l}\text { Shoe producer, } \\
\text { Logistic } \\
\text { partner, } \\
\text { customers }\end{array}\right.$ & $\begin{array}{l}\text { Materials } \\
\text { supplier, } \\
\text { Logistic partner, } \\
\text { customers, web } \\
\text { platform } \\
\text { provider }\end{array}$ & $\begin{array}{l}\text { Shoe producer, } \\
\text { Logistic partner, } \\
\text { customers }\end{array}$ & $\begin{array}{l}\text { Shoe producer, } \\
\text { Logistic partner, } \\
\text { customers }\end{array}$ \\
\hline 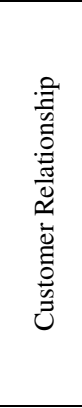 & $\mathrm{SC}$ & $\begin{array}{l}\text { Online profiles, } \\
\text { Social } \\
\text { networks, }\end{array}$ & $\begin{array}{l}\text { Online } \\
\text { profiles, } \\
\text { Social } \\
\text { networks, } \\
\text { Serious } \\
\text { games }\end{array}$ & $\begin{array}{l}\text { Online profiles, } \\
\text { Online } \\
\text { customized } \\
\text { school }\end{array}$ & Online profiles, & $\begin{array}{l}\text { Online profiles, } \\
\text { Social } \\
\text { networks, } \\
\text { Serious } \\
\text { games, Online } \\
\text { customized } \\
\text { school, } \\
\text { Customized } \\
\text { relationship, } \\
\text { Web- } \\
\text { campaign } \\
\end{array}$ \\
\hline 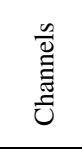 & $\mathrm{SC}$ & $\begin{array}{ll}\text { Online } & \text { store, } \\
\text { physical } & \text { store, } \\
\text { third } & \text { party } \\
\text { retailer } & \\
\end{array}$ & Online store & Online store & $\begin{array}{l}\text { Online store, } \\
\text { physical store }\end{array}$ & $\begin{array}{ll}\text { Online } & \text { store, } \\
\text { physical } & \text { store, } \\
\text { third } & \text { party } \\
\text { retailer } & \\
\end{array}$ \\
\hline 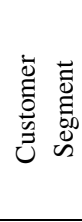 & PR & $\begin{array}{l}\text { Men \& Women, } \\
\text { Young web } \\
\text { users, } \\
\text { International } \\
\text { market }\end{array}$ & $\left\{\begin{array}{l}\text { Men } \quad \text { \& } \\
\text { Women, } \\
\text { Young web } \\
\text { users, } \\
\text { International } \\
\text { market }\end{array}\right.$ & $\begin{array}{lr}\text { Men \& } & \text { Women, } \\
\text { Young } & \text { web } \\
\text { users, } & \text { Local } \\
\text { market } & \\
\text { (Brazil) } & \end{array}$ & 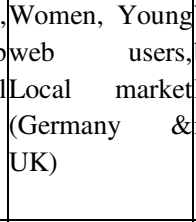 & $\begin{array}{l}\text { Women, aged } \\
\text { between 22-55, } \\
\text { International } \\
\text { market }\end{array}$ \\
\hline 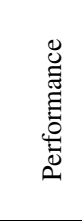 & $\mathrm{PR} / \mathrm{PS} / \mathrm{SC}$ & $\begin{array}{l}\text { Financial } \\
\text { indicators }\end{array}$ & $\begin{array}{l}\text { Financial } \\
\text { indicators }\end{array}$ & $\begin{array}{l}\text { Financial } \\
\text { indicators }\end{array}$ & $\begin{array}{l}\text { Financial } \\
\text { indicators }\end{array}$ & $\begin{array}{|ll|}\text { Financial } & \\
\text { indicators, } \\
\text { Limited set } & \text { of } \\
\text { indicators } & \text { to } \\
\text { measure } & \\
\text { efficacy } & \\
\end{array}$ \\
\hline
\end{tabular}

Going through different alternatives applied in each case study three main points should be noticed. In following sections we describe each of these pints. 


\subsection{Implementation of Key Alternatives for MC}

Analysis of collected data show that there are some alternatives applied by all five cases involved in this study. This emphasizes the fact that these alternatives should be considered as main attributes of a MC business model in footwear industry and possibly other industries. One of the most notable examples in this regard is "style customization" which is offered as a value proposition by all studied companies. This highlights the point that coming to a mass customization point, aesthetic/style is always a main aspect of customization in footwear industry. The same story is true for product modularization and components standardization which is a critical activity to increase efficiency in mass customization. Other examples in this regard are: Use of online configurator, Customers' requirement elicitation, Web-design and online store.

\subsection{Lack of Some MC Alternatives Proposed in Literature}

One of the notable results of data analysis relates to lack of some MC attributes which are proposed in different studies in literature but have not been implemented in none of the analyzed case studies. A clear example in this regard is knowledge management and knowledge creation. There are numerous studies mention knowledge management and creation as a key issue in mass customization. Franke and Piller point out the importance of acquired knowledge to create a barrier against switching suppliers while $\mathrm{Wu}$ et al. emphasize on role of knowledge management in level of service and quality [3],[12]. Surprisingly no company in this study implements knowledge management as a key activity. Another example extracted from analysis is integration of partners in supply chain in order to increase efficiency which has not been followed by analyzed cases. Integration of supplier means the extent to which a supplier could collaborate and manage some inter-organizational activities with manufacturer. In mass customization operations where standardize modularization has been implemented, the role of integrated suppliers are more tangible due to the need of long-term collaboration between manufacturer and supplier.

Implementation of flexible manufacturing systems is another neglected alternative which is considered only by company C. In this case it is not difficult to discover the reason since it is mainly due to the fact that only company $\mathrm{C}$ produces shoes in-house and consequently flexible manufacturing systems are considered as a main key resource for them, while the other four companies outsource the whole production which makes them independent to any agile production system. However the story is not so simple when it is related to integrated information system as a key resource. Based on our analysis company A is the only company using integrated information system to facilitate MC implementation. This can be due to many reasons such as high investment, non-readiness of supply chain for information integration, etc. Table 3 illustrates some of the main neglected alternatives by companies. 
Table 3. Implementation mapping of MC alternatives in literature in analyzed cases

\begin{tabular}{|l|c|}
\hline \multicolumn{1}{|c|}{ MC alternative } & Company \\
\hline Process modularization [2] & None \\
\hline Implement postponement [13] & $\mathrm{C}$ \\
\hline Web-platform and interaction system management [8],[2] & None \\
\hline Flexible manufacturing system [2],[9],[10] & $\mathrm{C}$ \\
\hline Integrating partners [8] & $\mathrm{A}$ \\
\hline Knowledge management and knowledge creation [3],[11] & None \\
\hline Support customers during co-design [1],[5] & $\mathrm{D}$ \\
\hline
\end{tabular}

\subsection{Lack of MC Performance Measurement}

As any other company, a mass customization company needs to use metrics in order to keep under control mass customization strategy and in particular to identify commonality and modularity level of products. Although monitoring and performance measurement is considered as a critical issue in MC but only one company uses a few metrics to measure the mass customization level while others never included it as a crucial step in their business model.

\section{$5 \quad$ Proposal of MC Business Model}

Taking into consideration all the previous considerations, a MC business model for footwear industry is proposed that could support a company in this sector to identify a possible path to implement MC. In order to develop the business model we tried to take into account best practices applied by each company however the proposed business model is not complete since as it has already been mentioned in previous section there are crucial MC alternatives in literature which have not been applied by none of the firms in this study. In this regard a complete business model can be developed through integration of current business model and a literature based $\mathrm{MC}$ business model. The following MC business model is a step forward to this aim since it clarifies the most important MC alternatives in a real industrial environment and possible challenges to implement mass customization. This might bring us one step closer to support companies in successful implementation of mass customization. The novelty of the proposed business model is not only based on what mentioned above but also on including supply chain elements in development of business model.

Configuration of the final business model can be an iterative activity by measuring performance of the developed business using indicators mentioned in performance block and revising other blocks to reach the required level of cost, customization and efficiency. 


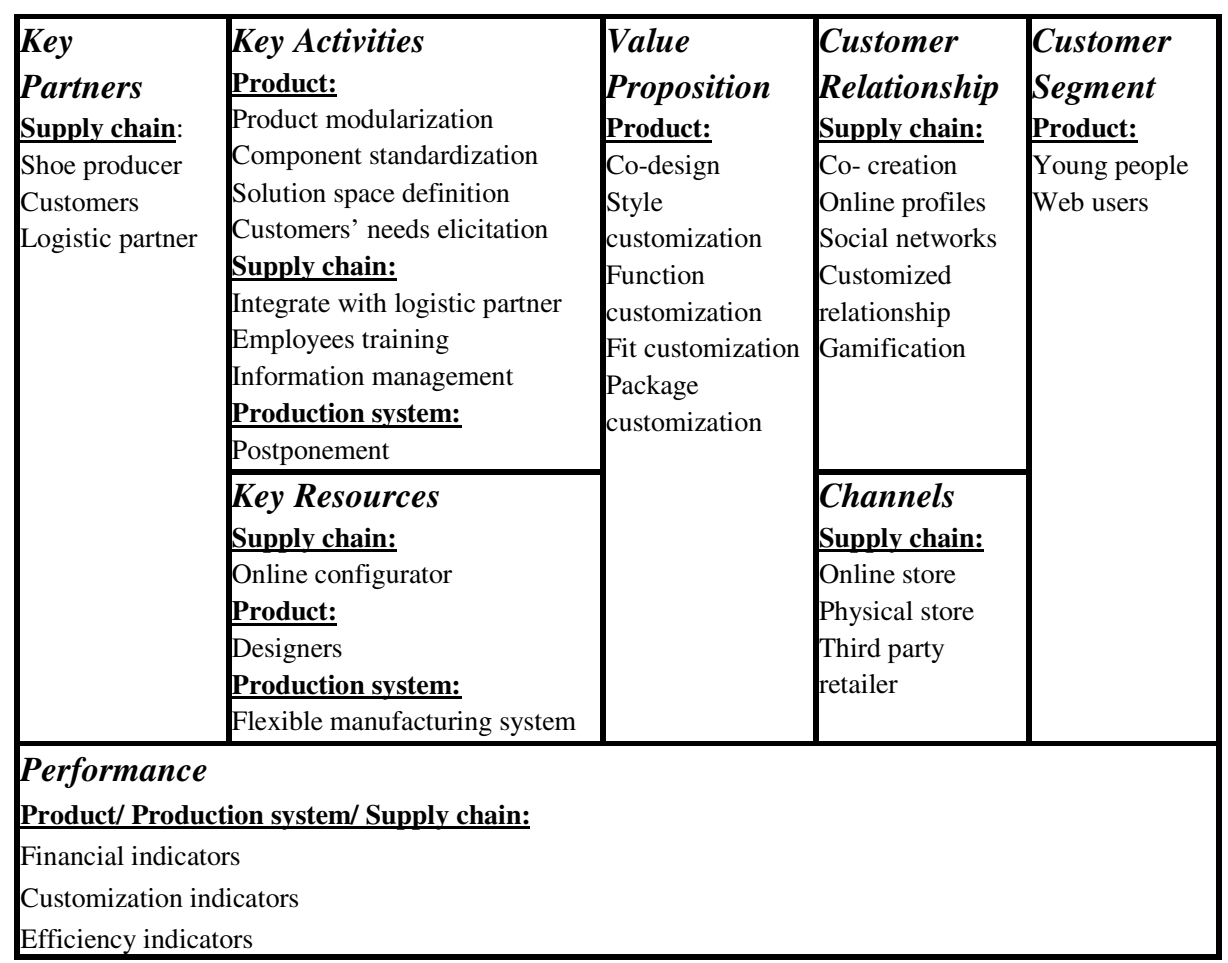

Fig. 2. Proposal of MC business model for footwear industry

\section{Conclusion}

The offer of mass customized shoes is a recent trend in the footwear industry and seems to be a promising business for the coming years that could fulfill evolving customer needs. Some brands have already developed the mass customized line and have entered the business since a few years ago, yet potentialities of mass customization could be further exploited being an opportunity for a higher number of companies. In this paper we propose a framework to support companies operating in shoe sector to develop a MC oriented business model. The proposal is a supporting tool for practitioners during the development of the business model. The decisional process can be more efficient since the framework provides not only a check-list of elements that need to be considered, but also a list of options that have been tested to be successful in the same context. On the other hand, this work adds also insights to the mass customization literature providing a work that take into account at the same time all the elements that need to be configured when a business model has to be developed. Given the high number of variables, the proposed model can be hardly generalized to other sectors, so it is a contribution to the footwear industry. Nonetheless, the applied methodology can be replicated in other industries where mass customization is an opportunity of growth. Next step of this research is the implementation of the proposed framework to support a company not yet mass customized to extend its offer in this direction. 


\section{References}

1. Abend, J.: Custom-made for the masses: is it time yet? Journal of Fashion Marketing and Management 2, 48-54 (1996)

2. Blecker, T., Abdelkafi, N.: The Development of a Component Commonality Metric for Mass Customization. Transaction on Engineering Management 54(1), 70-85 (2007)

3. Franke, N., Piller, F.T.: Configuration toolkits for mass customization setting a research agenda. International Journal of Technology Management 6(5/6), 578-599 (2003)

4. Jones, G.M.: Educators, Electrons, and Business Models: A Problem in Synthesis. Accounting Review 35(4), 619-626 (1960)

5. Oleson, J.D.: Path ways to agility: Mass customization in action. John Wiley \& Sons, Inc., New York (1998)

6. Osterwalder, A.: The Business Model Ontology - a proposition in a design science approach. Dissertation, University of Lausanne, Switzerland (2004)

7. Osterwalder, A., Pignuer, Y.: Model Generation: A Handbook for Visionaries, Game Changers, and Challengers, 1st edn. John Wiley \& Sons, NYC, Hoboken (2010)

8. Piller, F.T.: Mass customization: reflection on the state of the concept. International Journal of Flexible Manufacturing System 16(4), 313-334 (2004)

9. Pollard, D., Chuo, S.: Strategies for Mass Customization. Journal of Business \& Economics Research 6(7), 77-85 (2008)

10. Qiao, G., Lu, R., Mclean, C.: Flexible Manufacturing System for Mass Customization Manufacturing. International Journal of Mass Customization 1(2/3), 374-393 (2006)

11. Schreier, M.: The Value Increment of Mass-customized Products: An Empirical Assessment. Journal of Consumer Behaviour 5, 317-327 (2006)

12. Wu, J., Lin, I., Yang, M.H.: The impact of a customer profile and customer participation on customer relationship management performance. International Journal of Electronic Business Management 17(1), 57-69 (2009)

13. Xuan, G.X.: Positioning of customer order decoupling point in mass customization. In: Proceeding of the Sixth International Conference on Machine Learning and Cybernetics, Hong Kong, August 19-22 (2007) 